\title{
Pendidikan Anak dalam Keluarga Era Covid-19
}

\author{
Wahyu Trisnawati ${ }^{\circledR}{ }^{凶}$ Sugito $^{2}$ \\ Pendidikan Luar Sekolah, Universitas Negeri Yogyakarta \\ DOI: $\underline{10.31004 / \text { obsesi.v5i1.710 }}$
}

\begin{abstract}
Abstrak
Orang tua merupakan pendidik pertama dan utama dalam proses perkembangan anak. Penelitian ini bertujuan untuk mendeskripsikan peran sentral orang tua dalam pendidikan anak usia dini mengenai pelaksanaan tugas yang diberikan oleh guru pada masa pandemic coronavirus disease atau dikenal dengan virus covid-19. Penelitian ini menggunakan pendekatan kualitatif dengan metode deskriptif guna memperoleh informasi berkaitan dengan pendidikan anak usia dini pada era covid-19, bagaimana pendidikan yang diterapkan oleh keluarga pada era covid-19. Teknik pengumpulan data menggunakan observasi, wawancara, dan dokumentasi. Data yang sudah terkumpul dianalisis dengan langkah reduksi data, penyajian data, penarikan kesimpulan dan verifikasi. Hasil penelitian menunjukkan bahwa orang tua memberikan pendampingan kepada anak dengan cara membantu anak mengerjakan tugas, belajar dari lingkungan sekitar dan memberikan pengetahuan mengenai covid-19. Orang tua telah berhasil menciptakan suasana belajar yang nyaman yaitu dengan memberikan fasilitas belajar yang memadai, melakukan pendampingan dalam penyelesaian tugas, dan memberikan rewards.
\end{abstract}

Kata Kunci: pendidikan anak; keluarga; covid-19.

\begin{abstract}
Parents are the first and foremost educators in the process of child development. This study aims to describe the central role of parents in early childhood education regarding the implementation of tasks given by teachers during the pandemic coronavirus disease, known as the covid-19 virus. This study uses a qualitative approach with descriptive methods to obtain information related to early childhood education in the Covid-19 era, how education is applied by families in the Covid-19 era. Data collection techniques using observation, interviews, and documentation. The data that has been collected is analyzed using data reduction steps, data presentation, drawing conclusions and verification. The results showed that parents provided assistance to children by helping children with assignments, learning from the surrounding environment and providing knowledge about Covid-19. Parents have succeeded in creating a comfortable learning atmosphere, namely by providing adequate learning facilities, providing assistance in completing assignments, and providing rewards.
\end{abstract}

Keywords: children's education; family; covid-19.

Copyright (c) 2020 Wahyu Trisnawati, Sugito

$\triangle$ Corresponding author:

Email Address : wahyutrisnawati.2018@student.uny.ac.id ( Jl.Colombo No.1, Karang Malang, Depok, Sleman, Yogyakarta ). Received 12 August 2020, Accepted 25 August 2020, Published 26 August 2020 


\section{PENDAHULUAN}

Pendidikan pertama pada anak tumbuh dari lingkungan keluarga, sehingga anak pertama kali mendapatkan bimbingan serta pendidikan bukan dari lingkungan sekolah melainkan dari lingkungan keluarga. Keluarga memiliki tugas utama untuk pendidikan anak, yaitu sebagai acuan dasar mengenai pendidikan keagamaan, nilai budaya, serta nilai moral sebagai modal dalam bersosialisasi dalam lingkungan masyarakat (Supriyono dkk., 2015). Pendidikan dalam lingkungan keluarga menjadikan orang tua sebagai pendidik utama pada anak, menjadi salah satu proses dalam pendidikan informal. Setiap keluarga memiliki strategi yang berbeda dalam mendidik anak, disebabkan oleh input yang berbeda sehingga memiliki proses dengan menghasilkan output yang berbeda.

Rendahnya pengetahuan dan pemahaman keluarga dalam kedudukan keluarga dan tanggung jawab mengenai pendidikan anak di rumah. Kurangnya pengetahuan dan pemahaman orang tua disebabkan oleh kurangnya inisiatif orang tua untuk belajar guna mendukung pendidikan anak dalam keluarga Tanpa orang tua sadari sesungguhnya keluarga memiliki peran penting dalam perkembangan dan pendidikan anak. Perlu ditingkatkan pengetahuan orang tua mengenai cara mendidik anak agar berjalan optimal. Era digital mempermudah orang tua untuk mencari informasi yang valid dan berasal dari sumber-sumber yang terpercaya.

Keperdulian orang tua merupakan faktor penentu keberhasilan anak dalam belajar, tidak lain merupakan faktor eksternal (Sudirman., 2013). Orang tua memiliki peran penting dalam menjaga dan membina perkembangan anak dari fase ke fase, yaitu pada awal perkembangan dan pertumbuhan anak atau pada masa golden age. Pendidikan anak usia dini merupakan tatanan dasar dalam membangun kepribadian anak. Kesatuan antara ibu dan ayah menjadi faktor penting dalam memperkokoh pendidikan anak (Makhmudah, 2018). Pendidikan dalam keluarga menjadi salah satu upaya untuk mencerdaskan kehidupan bangsa melalui pengalaman yang didapatkan seumur hidup. Pendidikan dalam lingkungan keluarga memberikan pengetahuan dan praktik mengenai keagamaan, budaya, dan pergaulan dalam lingkungan masyarakat (Rahmah, 2017).

Saat sekarang ini seluruh negara di dunia, termasuk Indonesia sedang dilanda bencana yang berkaitan dengan kesehatan dan dikenal dengan coronavirus disease atau covid19. Virus ini tidak hanya mengancam kesehatan masyaakat melainkan juga perekonomian dan pendidikan. Perhatian masyarakat berfokus pada bagaimana strategi untuk mengobati atau menghindari covid-19. Wabah covid-19 masih berlangsung dan belum terdapat tanda mereda, seluruh aktivitas dilakukan di rumah melalui sistem dalam jaringan baik dalam dunia pendidikan atau dunia pekerjaan. Mendikbud meneribitkan Surat Edaran Nomor 4 Tahun 2020 tentang Pelaksanaan Pendidikan dalam Masa Darurat Coronavirus Disease (Covid-19) bahwa penerapan belajar dari rumah bukan berarti guru hanya memberikan tugas kepada siswa namun ikut berkomunikasi dengan orang tua untuk membantu siswa dalam mengerjakan tugas yang diberikan (Aji, 2020).

Sektor pendidikan, organisasi pendidikan, keilmuan, dan kebudayaan perserikatan bangsa-bangsa atau UNESCO menindaklanjuti bahwa virus covid-19 berdampak pada dunia pendidikan. Hampir seluruh negara memberlakukan kebijakan untuk belajar dari rumah tanpa tatap muka di sekolah. Hal tersebut merubah sistem pendidikan sehingga berdampak pada kegiatan belajar mengajar menjadi terganggu dan siswa terancam kehilanganhak-hak belajarnya.

Terkait jumlah siswa, hingga 15 Juni 2020 terdapat 94 persen siswa yang berada pada zona kuning, orange, dan merah yang tersebar dalam 429 kabupaten/kota sehingga pelaksanaan pembelajaran masih berlangsung belajar dari rumah. Adapun siswa yang berada pada zona hijau berjumlah 6 persen (Kebudayaan et al., 2009). Berdasarkan kondisi tersebut, Kemendikbud mengeluarkan kurikulum darurat pandemi covid-19 sebagaimana modul dala pembelajaran anak usia dini adalah menggunakan prinsip bermain merupakan 
DOI: 10.31004/obsesi.v5i1.710

belajar. Proses pembelajaran pada anak usia dini terjadi pada saat anak bermain dan melakukan kegiatan sehari-hari (Jpnn.com, 2020).

Wabah covid-19 mengharuskan setiap orang untuk menjaga jarak sehingga dampaknya dapat dirasakan secara langsung dalam semua sisi kehidupan. Anak usia dini menjadi salah satu korban pada efek lingkungan pendidikan, mereka diliburkan dan diganti belajar dari rumah (Oktaria \& Putra, 2020). Pada abad ke-21, covid-19 mengharuskan pembelajaran dilakukan secara daring. Menariknya di tengah wabah covid-19 berdampak pada segala keterbatasan khususnya pada pendidikan anak usia dini. Peran orang tua menjadi kunci utama dalam pembelajaran anak sehingga minat belajar anak tidak menurun meskipun proses pembelajar tidak dilangsungkan dengan tatap muka. Orang tua bukan hanya pendidik sebagai orang tua tetapi memiliki peran sebagai guru pada lembaga pendidikan.

Pada masa pandemi, orang tua banyak memiliki waktu bersama anak-anaknya sehingga anak cenderung berkembang melalui pengasuhan yang diberikan orang tua. Orang tua di Desa Tanggeran RT02/RW01 tidak pernah belajar bagaimana cara mengajar anak yang baik, tetapi cenderung spontan dalam berkomunikasi dengan anak. Keterlibatan orang tua menjadi hal penting dalam membantu anak dari keterbatasan belajar, meningkatkan hubungan sosial anak dan mengajarkan anak mengenai kesadaran akan minat belajar. Namun belum sepenuhnya terlaksana pada pembelajaran keluarga di Desa Tanggeran RT02/RW01.

Setiap orang tua memiliki cara yang berbeda dalam memperlakukan anaknya dan setiap pola asuh memiliki kekurangan serta kelebihan. Orang tua sesuai dengan pola asuhnya dituntut untuk menciptakan kondisi yang berkualitas sehingga orang tua mampu memberikan stimulus dengan baik. Tujuannya adalah supaya potensi dalam diri anak dapat berkembang maksimal. Apabila pola asuh orang tua dan stimulus yang diberikan tidak sesuai maka berpotensi akan salah arah.

Menjadi contoh yang baik merupakan metode terbaik dalam mengajarkan nilai-nilai kehidupan kepada anak saat pandemi berlangsung. Anak memiliki kebiasaan yang dicontohkan dari kebiasaan orang tua atau keluarga yang tinggal bersama dalam satu rumah. Anak akan menirukan perilaku keluarganya yang menjadi kebiasaan dalam kehidupan sehari-hari. Pendekatan pembelajaran pada anak sebaiknya memperhatikan prinsip-prinsip sebagai berikut: (1) Belajar harus menantang pemahaman anak; (2) Memulai proses belajar mengajar dari pengetahuan yang dimiliki anak; (3) Menggunakan alam sebagai sarana belajar mengajar; (4) Belajar dilakukan sambil bermain; (5) Belajar membekali keterampilan hidup; (6) Proses belajar mengajar dilakukan melalui pengetahuan sensorik dan indrawi; (7) Belajar sambil memberikan kesempatan kepada anak untuk melakukan (Erzad, 2018). Akan tetapi prinsip belajar anak usia dini belum dipahami oleh oang tua, sehingga orang tua menerapkan strategi pembelajaran secara spontan dan menciptakan lingkungan belajar yang nyaman bagi anak.

Fungsi edukatif orang tua penting dalam proses membimbing dan mendidik anak. Merealisasikan fungsi edukatif dilakukan orang tua dengan cara memahami pola yang harus diberikan supaya pengetahuan yang diberikan kepada anak lebih bersifat terarah. Orang tua perlu pengetahuan lebih luas untuk mewujudkan harapan yang diinginkan (Setiani, 2018). Inisiatif belajar belum tumbuh pada seluruh orang tua di Desa Tanggeran RT02/RW01, kendala yang dialami adalah tidak mempunyai dana untuk membeli buku, kemalasan untuk membaca buku karena merasa banyak pekerjaan rumah yang harus dikerjakan, dan tidak memiliki motivasi tinggi untuk menambah pengetahuan berkaitan dengan pendidikan anak usia dini. Meskipun setiap orang tua sudah memiliki smartphone tetapi tidak memahami bahwa smartphone dapat menghasilkan informasi yang relevan dan valid.

Anak usia dini di Desa Tanggeran RT02/RW01 pada masa covid-19 lebih banyak menghabiskan waktu untuk belajar di rumah. Meskipun orang tua merasa kesulitan untuk melakukan pembelajaran di rumah tetapi hal tersebut merupakan kegiatan yang aman 
dalam pencegahan virus covid-19. Rendah atau tingginya status pendidikan orang tua tidak menjadi acuan dalam mendidik anak, tetapi kreativitas dan pengetahuan yang dimiliki orang tua menjadi faktor pendukung pendidikan anak dalam keluarga. Hal tersebut akan berpengaruh terhadap keberhasilan pelaksanaan pendidikan anak dalam keluarga.

Peneliti memfokuskan kajian pada pendidikan anak berupa pendampingan orang tua dalam pengerjaan tugas sekolah anak dan keterlibatan orang tua dalam memberikan lingkungan pembelajaran yang nyaman. Upaya pendampingan dilakukan orang tua dalam berbagai cara seperti membantu anak ketika merasa kesulitan, mengadakan pengajaran, atau melakukan pembelajaran via online (Kurniati et al., 2020). Pendampingan dan pendidikan pada anak usia dini dengan presentase 75 persen merupakan tanggung jawab orang tua dan 25 persen merupakan tanggung jawab guru PAUD. Orang tua mempunyai tanggung jawab yang lebih besar dalam pendidikan anak (Putra, 2020). Guru memberikan tugas melalui aplikasi WhatsApp dan memberikan pengarahan kepada orang tua mengenai petunjuk pengerjaan tugas. Selain memberikan tugas, guru bertugas, guru berhak untuk memberikan penguatan kepada siswa dengan cara memberikan apreasiasi melalui Voice Note atau dengan memberikan stiker bintang pada hasil tugas yang telah dikerjakan oleh siswa (Setyowahyudi \& Ferdiyanti, 2020). Berdasarkan temuan dari peneliti terdahulu mengenai pendidikan anak usia dini dalam keluarga pada era covid-19 dapat dipahami bahwa pembelajaran dari rumah via online merupakan tanggung jawab orang tua dalam memberikan lingkungan belajar yang nyaman sehingga anak termotivasi untuk mengerjakan tugas yang diberikan guru.

\section{METODOLOGI}

Jenis penelitian yang digunakan oleh peneliti adalah penelitian deskriptif kualitatif. Menurut (Malhotra, 2005) pendekatan kualitatif merupakan pendeskripsian masalah penelitian berdasarkan deskripsi isu atau kebutuhan mengenai penjelasan mengenai beberapa variabel. Penelitian ini menggunakan pendekatan kualitatif karena penelitian berhubungan dengan fenomena sosial di masyarakat, yaitu menganalisis pendidikan anak dalam keluarga pada era covid-19. Subjek penelitian pada artikel ini adalah lima keluarga dengan ibu bekerja dan memiliki anak usia dini serta berdomisili di Desa Tanggeran RT 02/RW01, Kabupaten Banyumas. Penelitian dilaksanakan dengan mendatangi rumah satu per satu.

Penelitian dilaksanakan pada bulan Juli 2020, melalui prosedur observasi lapangan, pengambilan data, dan analisis data penelitian. Peneliti melakukan crosscheck mengenai kevalidan data kepada guru dan anggota keluarga yang terdapat satu rumah dengan orang tua anak usia dini. Proses pembelajaran anak usia dini dihimbau untuk melaksanakan pembelajaran dari rumah masing-masing. Guru memantau perkembangan siswa dan memberikan tugas melalui sosial media (WhatsApp).

Teknik pengumpulan data yang utama dilaksanakan peneliti adalah teknik observasi dan wawancara. Analisis data yang digunakan peneliti yaitu dengan langkah-langkah: (1) reduksi data; (2) penyajian data; dan (3) kesimpulan atau verifikasi. Adapun rancangan penelitian peneliti adalah sebagai berikut:

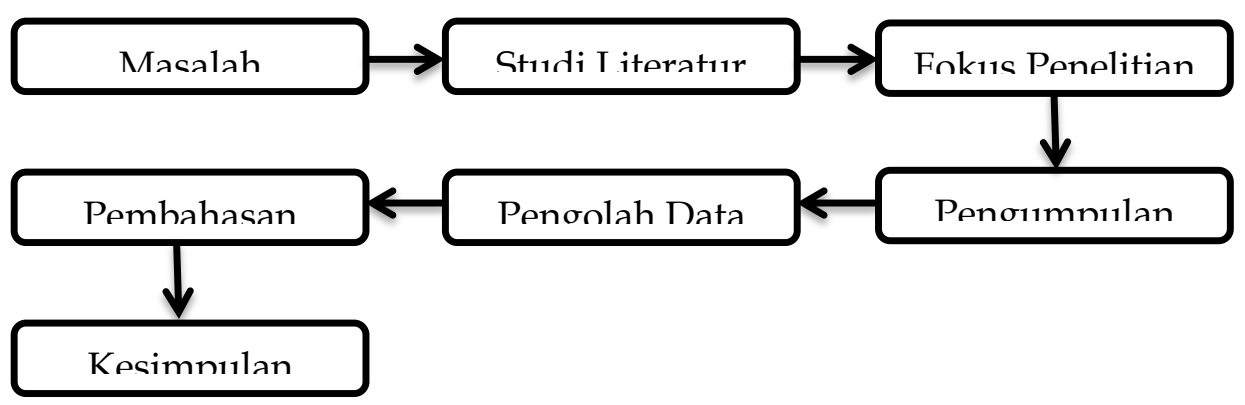

Gambar 1. Desain Penelitian 
DOI: 10.31004 /obsesi.v5i1.710

\section{HASIL DAN PEMBAHASAN}

\section{Pendampingan Orang Tua dalam Pengerjaan Tugas Anak}

Pandemi coronavirus disease atau covid-19 menyebabkan proses belajar siswa mengalami perubahan dari sebelumnya. Sebelum pandemi berlangsung kegiatan belajar siswa berpusat pada guru sebagai edukator melalui kegiatan bermain sambil belajar yang dilaksanakan di lembaga sekolah, akan tetapi saat ini proses belajar berpusat kepada orang tua sebagai pendidik utama. Kegiatan belajar dari rumah merupakan kegiatan yang menantang bagi orang tua. Awal pandemi covid-19, tiga dari lima keluarga merasa kesulitan untuk beradaptasi sebagai pendidik bagi anaknya dalam proses belajar. Kesulitan disebabkan oleh kebiasaan orang tua menyerahkan tanggung jawab pendidikan kepada lembaga sekolah.

Tugas diberikan guru melalui grup "WhatsApp" untuk mendukung proses belajar anak. Berdasarkan observasi peneliti, orang tua melakukan pendampingan terhadap anak dalam proses mengerjakan tugas serta membantu proses tersebut dari awal proses hingga selesai. Namun guru tetap melakukan pemantauan melalui grup "WhatsApp", jika orang tua mengalami kesulitan maka guru akan memberikan penjelasan lebih rinci mengenai tugas yang diberikan. Orang tua berusaha menjadi pendidik yang baik bagi anaknya. Berdasarkan hasil wawancara, dua keluarga berusaha untuk mendapatkan pengetahuan lebih mengenai materi-materi yang diberikan oleh guru dengan cara membaca buku atau menonton youtube. Hal tersebut berdampak positif dan lebih mempermudah orang tua dalam mendampingi anak belajar.

Belajar dari rumah memberikan peluang kepada anak usia dini untuk belajar dari pengalaman orang tua. Orang tua memberikan waktu kepada anak untuk bermain serta tidak memaksakan anak untuk belajar setiap pagi, siang, dan sore. Tetapi orang tua memberikan stimulus kepada anak untuk menumbuhkan motivasi belajar pada diri anak. Pengalaman orang tua direalisasikan dalam proses belajar anak, lima keluarga memiliki prinsip yang sama yaitu menjadikan hal yang dialami di masa kecil sebagai pedoman dalam memberikan edukasi kepada anak. Tetapi orang tua perlu menggabungkan pengalaman dengan pengatahuan yang dipelajari melalui buku atau youtube.

Setiap keluarga memiliki cara yang berbeda dalam memberikan pendampingan terhadap anak dalam pengerjaan tugas begitu juga dengan orang tua yang menjadi subjek penelitian peneliti. Ada yang memberikan kebebasan terlebih dahulu kepada anak untuk bermain kemudian melanjutkan belajar, memberikan jadwal anak belajar sesuai jam belajar di sekolah, mengerjakan tugas terlebih dahulu kemudian diperbolehkan untuk bermain, memberikan kesempatan kepada anak untuk mempersiapkan alat dan bahan yang akan digunakan untuk mengerjakan tugas hingga proses merapikan setelah selesai belajar, serta melaksanakan pembelajaran di rumah dengan prinsip learning by doing. Meskipun strategi yang diterapkan setiap keluarga berbeda, namun memiliki tujuan yang sama yaitu memberikan pendampingan kepada anak dalam penyelesaian tugas yang diberikan oleh guru.

Berikut adalah dokumentasi proses pengerjaan tugas pada proses belajar dari rumah:
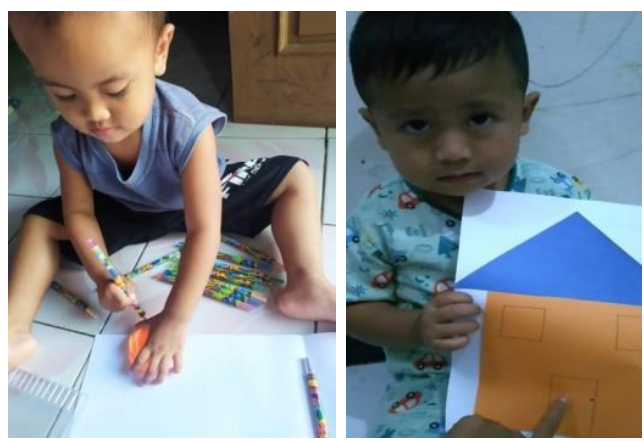

Gambar 2. Dokumentasi Proses Pengerjaan Tugas 
Proses pendidikan anak dalam keluarga belum seluruh orang tua menerapkan prinsip-prinsip belajar untuk anak usia dini. Orang tua lebih berfokus pada semangat anak dalam megerjakan tugas, karena hal tersebut menurut orang tua dapat dijadikan stimulus untuk menyelesaikan tugas yang diberikan oleh guru. Guru perlu memantau dan melakukan wawancara dengan orang tua mengenai cara yang diberikan dalam melaksanakan pendidikan anak, demikian dapat dilakukan evaluasi mengenai keberhasilan program belajar dari rumah.

Tidak semua orang tua memiliki pemahaman yang sama, meskipun dengan tugas yang sama tetapi orang tua memberikan stimulus kepada anak dengan cara yang berbedabeda. Orang tua memiliki inisiatif untuk memberikan penghargaan atau pujian kepada anak ketika anak sudah selesai mengerjakan tugas. Pujian tersebut dalam bentuk kalimat, dan terlihat anak merasa senang. Selain orang tua memberikan pujian kepada anak, guru memberikan penghargaan dalam bentuk bintang di hasil tugas yang diberikan kepada guru. Hal tersebut memberikan bukti bahwa anak memiliki semangat lebih jika hasil karyanya dihargai oleh orang lain di sekelilingnya.

\section{Menciptakan Lingkungan Belajar yang Nyaman}

Anak usia dini merasakan kebosanan untuk belajar di rumah saat pandemi, karena terdapat larangan untuk berkerumun sebagai akibat dari coronavirus disease atau covid-19. Suasana belajar yang nyaman ditumbuhkan oleh kondisi lingkungan sekitar dan orangorang disekitar tempat belajar. Orang tua memiliki hak untuk memberikan suasana belajar yang nyaman dan menyenangkan sehingga dapat menumbuhkan motivasi belajar pada diri anak. Berdasarkan prinsip pendidikan anak usia dini, sebaiknya orang tua melaksanakan pembelajaran dengan cara bermain sambil belajar. Orang tua dituntut untuk kreatif dalam menciptakan pembelajaran yang menyenangkan sehingga anak merasakan kenyamanan dalam proses belajar. Namun, tiga dari lima keluarga belum melaksanakan prinsip bermain sambil belajar.

Orang tua memberikan kebebasan kepada anak untuk bermain setelah tugas sekolah terselesaikan. Tetapi hal tersebut membuat anak merasa kurang nyaman dalam mengerjakan tugas. Sedikit paksanaan membuat anak sesekali mogok untuk mengerjakan tugas yang diberikan guru. Meskipun demikian, orang tua belum memahami solusi yang sebaiknya diterapkan dalam menghadapi kendala yang terjadi. Orang tua memberikan pengetahuan kepada anak tetap sesuai dengan strategi yang menurutnya benar. Dua dari lima keluarga telah menerapkan prinsip bermain sambil belajar, orang tua ikut terlibat ketika anak bermain sambil memberikan materi pengetahuan. Berdasarkan hasil wawancara peneliti mendeskripsikan bahwa orang tua memberikan pengetahuan bersumber dari pengalaman yang telah didapatkan dan materi yang telah dipelajari dari membaca buku atau menonton youtube.

Rendahnya pengetahuan orang tua berdampak pada pendidikan yang diterapkan kepada anak. Terpantau dari cara belajar yang diberikan orang tua kepada anak. Sifat rajin yang terdapat pada diri orang tua dan keinginan yang kuat untuk mendapatkan pengetahuan melalui membaca dan belajar dari sumber-sumber relevan akan memberikan efek kreatif dalam merealisasikan proses pembelajaran di rumah. Pendidikan yang diberikan orang tua di rumah tidak hanya sebatas mengerjakan tugas dari guru melainkan belajar dari lingkungan sekitar dan belajar dari media digital. Saat sekarang anak usia dini dapat belajar mengenai coronavirus disease atau covid-19, orang tua memberikan pengetahuan tentang covid-19 dengan membiasakan pola hidup sehat. Hal tersebut sudah diterapkan oleh seluruh subjek penelitian dengan mengajarkan anak tentang cuci tangan yang benar, memakai masker saat keluar rumah, dan tidak boleh berkerumun dengan banyak orang. Pengalaman yang dialami oleh anak usia dini akan terekam hingga dia dewasa. 
DOI: 10.31004/obsesi.v5i1.710

Kenyamanan belajar pada anak usia dini dapat dimulai dengan menyediakan fasilitas belajar yang memadai, pendampingan orang tua dalam proses mengerjakan tugas, dan pemberian rewards kepada anak saat selesai mengerjakan tugas. Ketiga hal tersebut sudah terlaksana 90 persen, seluruh orang tua memberikan fasilitas belajar sesuai dengan kebutuhan anak, memberikan pendampingan saat pengerjaan tugas, serta memberikan pujian ketika selesai mengerjakan tugas. Orang tua menyadari bahwa hal tersebut menjadi stimulus anak sehingga tidak banyak drama yang berakibat anak mogok belajar.

\section{Pembahasan}

Pada kondisi normal umumnya orang tua berada pada kondisi bekerja namun pada masa pandemi orang tua memiliki tanggung jawab terhadap pendidikan anak melalui pembelajaran dari rumah. Orang tua memberikan pendampingan kepada anak pada saat mengerjakan tugas yang diberikan oleh guru. Selain pendampingan, orang tua memberikan pengetahuan kepada anak yang bersumber dari lingkungan sekitar dan media digital. Hal demikian sejalan dengan pendapat (Oktaria, 2013) menjelaskan bahwa waktu kebersamaan anak dan orang tua di rumah tidak hanya dihabiskan dengan menonton televisi dan bermain smartphone, tetapi orang tua diberikan kesempatan untuk memperhatikan perkembangan dan pendidikan anak.

Belum seluruh orang tua memiliki inisiatif untuk menambah pengetahuan melalui media buku, youtube, atau media lain yang relevan. Orang tua di Desa Tanggeran RT 02/RW01 sebesar 40 persen yang memiliki antusias tinggi menambah pengetahuan, selebihnya belum memiliki motivasi untuk menambah pengetahuan. Apabila orang tua memiliki pengetahuan luas tentang pendidikan anak usia dini maka akan memberikan pembelajaran yang tepat. Hal tersebut sesuai dengan pendapat (Oktaria \& Putra, 2020) bahwa sebagai orang tua perlu belajar terus mengenai ilmu bagaimana parenting yang sesuai pada anak usianya dan bagaimana memberikan pembelajaran yang tepat pada anak sedini mungkin.

Peran sentral orang tua dalam pendidikan anak di era pandemi memberikan keberhasilan karena umumnya orang tua merupakan pendidik utama bagi anak usia dini. Hal tersebut sudah dilaksanakan orang tua selama terdapat aturan untuk belajar dari rumah. Menciptakan lingkungan belajar telah direalisasikan oleh orang tua sesuai dengan strategi masing-masing keluarga. Sejalan dengan hasil penelitian (Irma dkk, 2019) bahwa keberhasilan proses belajar mengajar pada anak usia dini bukan hanya tanggung jawab pemerintah dan lembaga sekolah melainkan orang tua sebagai pendidik pertama dan utama yang berperan secara utuh dalam keberhasilan pembelajaran anak. Guru, siswa dan orang tua merupakan elemen unsur belajar mengajar anak usia dini yang bertindak saling mempengaruhi.

Pemberian tugas oleh guru dilakukan melalui WhatsApp memberikan rendahnya interaksi antara guru dan siswa. Sejalan dengan hasil penelitian (Muhdi \& Nurkolis, 2021) bahwa implementasi kebijakan e-learning belum terlaksana secara efektif sehingga guru perlu menyusun rancangan pembelajaran dengan lebih memperhatikan kemaksimalan tingkat interaksi antara guru dan siswa. Sedangkan Wahyudi ( 2019) menjelaskan bahwa pendidikan keluarga perlu memperhatikan realitas sehingga orang tua lebih memperhatikan penerapan pendidikan yang tepat.

Orang tua berpedoman terhadap pengetahuan dan pengalaman dalam pendidikan anak sehingga orang tua dijadikan contoh oleh anak dalam proses belajar. Hal tersebut sejalan dengan hasil penelitian (Andriyani, 2018) bahwa keluarga merupakan lingkungan yang sangat berpengaruh terhadap pendidikan dan perkembangan anak usia dini. Orang tua menjadi contoh dalam anak berproses, pada dasarnya pendidikan anak usia dini merupakan hak anak yang diperoleh dari orang tuanya bukan pemberian orang tua kepada anak. 
Orang tua menciptakan kenyamanan belajar yang dijadikan sebagai stimulus semangat belajar pada anak sehingga anak tidak banyak drama yang berakibat mogok belajar. Tidak berbeda dengan pendapat (Mustofa \& Ishak, 2017) bahwa rasa bosan yang dirasakan oleh anak dapat diatasi dengan menerapkan berbagai variasi metode pembelajaran. Sebagai pendidik harus memahami lebih dari satu metode, karena tanpa adanya metode dalam pembelajaran maka proses pendidikan anak sia-sia. Gairah belajar pada anak perlu dibangkitkan, dipupuk, serta dikembangkan.

Anak memiliki rasa ingin tahu yang besar sehingga dalam pelaksanaan pendidikan dari rumah perlu memperhatikan kenyamanan belajar anak sehingga tidak berakibat anak mogok belajar. Hal tersebut sejalan dengan hasil penelitian (Sofiani et al., 2020) bahwa anak usia dini cenderung senang dengan hal baru yang didapatkan melalui aktivitas bermain. Tidak jarang anak bermain dan memuaskan rasa penasaran dengan media digital, salah satunya adalah smartphone. Namun tanpa disadari, hal tersebut berpengaruh terhadap perkembangan anak. Rahimah \& Muzdhalifah (2019)menjelaskan bahwa pola asuh orang tua merupakan faktor penting dalam mengembangkan atau menghambat perkembangan kecerdasan anak.

\section{SIMPULAN}

Pandemi covid-19 memberikan tanggung jawab kepada orang tua menjadi pendidik utama bagi anak. Orang tua bertugas sebagai pendamping anak dalam mengerjakan tugas yaitu dengan cara membantu anak mengerjakan tugas, belajar dari lingkungan sekitar, dan memberikan pengetahuan kepada anak mengenai covid-19. Setiap keluarga memiliki cara berbeda dalam melaksanakan pendidikan dari rumah. Pelaksanaan pendidikan anak dalam keluarga belum sepenuhnya memperhatikan prinsip belajar anak usia dini namun orang tua sudah berhasil menciptakan kenyamanan belajar pada anak. Terlihat dari pemberian fasilitas belajar yang memadai, pendampingan dalam pengerjaan tugas, pemberian rewards oleh orang tua dan guru. Keberhasilan tersebut terpantau dari antusias anak dalam proses belajar.

\section{UCAPAN TERIMAKASIH}

Ucapan terimakasih penulis sampaikan kepada informan yang telah memberikan informasi kepada peneliti mengenai kajian pendidikan anak dalam keluarga. Penulis juga berterima kasih kepada tim reviewer dan editor Jurnal Obsesi yang sudah memberikan kesempatan dan membantu perbaikan artikel penulis sehingga siap untuk diterbitkan.

\section{DAFTAR PUSTAKA}

Aji, T. (2020). Pendidikan Karakter di Masa Pandemi, Menjadi Tanggung Jawab Siapa? Bkdjakarta.Kemenag.Go.Id.

Andriyani, I. N. (2018). Pendidikan Anak dalam Keluarga di Era Digital. FIKROTUNA, 7(1), 789-802. https://doi.org/10.32806/jf.v7i1.3184

Erzad, A. M. (2018). Peran Orang Tua dalam Mendidik Anak Sejak Dini di Lingkungan Keluarga. ThufuLA: Jurnal Inovasi Pendidikan Guru Raudhatul Athfal, 5(2), 414. https:// doi.org/10.21043/thufula.v5i2.3483

Irma, C. N., Nisa, K., \& Sururiyah, S. K. (2019). Keterlibatan Orang Tua dalam Pendidikan Anak Usia Dini di TK Masyithoh 1 Purworejo. Jurnal Obsesi : Jurnal Pendidikan Anak Usia Dini, 3(1), 214. https:// doi.org/10.31004/obsesi.v3i1.152

Jpnn.com. (2020). Kemendikbud Terbitkan Kurikulum Darurat Pandemi Covid-19. Www.Jppn.Com.

Kebudayaan, K. P. dan, Agama, K., Kesehatan, K., \& Negeri, K. D. (2009). Panduan Penyelenggaraan Pembelajaran Pada Tahun Ajaran Dan Tahun Akademik Baru Di Masa Pandemi Corona Virus Disease (Covid-19). Keputusan Bersama, 2, 129. 
DOI: 10.31004/obsesi.v5i1.710

Kurniati, E., Nur Alfaeni, D. K., \& Andriani, F. (2020). Analisis Peran Orang Tua dalam Mendampingi Anak di Masa Pandemi Covid-19. Jurnal Obsesi : Jurnal Pendidikan Anak Usia Dini, 5(1), 241. https:/ / doi.org/10.31004/ obsesi.v5i1.541

Makhmudah, S. (2018). Penguatan Peran Keluarga dalam Pendidikan Anak. Martabat: Jurnal Perempuan Dan Anak, 2(2), 271-275. https:// doi.org/10.21274/martabat.2018.2.2.269286

Malhotra. (2005). Riset Penelitian Jakarta.

Muhdi, \& Nurkolis. (2021). Keefektivan Kebijakan E-Learning berbasis Sosial Media pada PAUD di Masa Pandemi Covid-19. Jurnal Obsesi : Jurnal Pendidikan Anak Usia Dini, 5(1), 212-228. https:// doi.org/10.31004/obsesi.v5i1.535

Mustofa, A., \& Ishak. (2017). Urgensi Pendidikan Shalat pada Anak dalam Keluarga: Studi Analisis Hadith tentang Hukuman Bagi Anak Tidak Shalat. Murrobi: Jurnal Ilmu Pendidikan, 1(1), 14.

Oktaria, R. (2013). Implementasi Pendekatan Pembelajaran dalam Pendidikan Anak Usia Dini. Nizham Jounal of Islamic Studies, 1(2), 174-184.

Oktaria, R., \& Putra, P. (2020). Pendidikan Anak dalam Keluarga sebagai Strategi Pendidikan Anak Usia Dini Saat Pandemi Covid-19. Jurnal Ilmiah PESONA PAUD, 7(1), 41-51.

Putra, I. P. (2020). Orang Tua Paling Menentukan Pendidikan Anak Usia Dini saat Pandemi. Medcom.Id.

Rahimah, \& Muzdhalifah. (2019). Pengaruh Pola Asuh Orang Tua Terhadap Kecerdasan Intrapersonal dan Kecerdasan Interpersonal Anak Usia Dini. Al Athfaal: Jurnal Ilmiah Pendidikan Anak Usia Dini, 2(2), 2.

Rahmah, S. (2017). Peran Keluarga dalam Pendidikan Akhlak. Al-Hiwar : Jurnal Ilmu Dan Teknik Dakwah, 4(6), 14. https:/ / doi.org/10.18592/al-hiwar.v4i6.1213

Setiani, R. E. (2018). Pendidikan Anak dalam Lingkungan Keluarga (Perspektif Agama dan Sosial-Budaya). Yin Yang, 11(1), 115-116. https://doi.org/10.24090/yinyang.v13i1.2018.pp105-116

Setyowahyudi, R., \& Ferdiyanti, T. (2020). Keterampilan Guru PAUD Kabupaten Ponorogo Dalam Memberikan Penguatan Selama Masa Pandemi COVID-19 Rendy. Jurnal Golden Age, 04(1), 100-111.

Sofiani, I. K., Mufika, T., \& Mufaro'ah, M. (2020). Bias Gender dalam Pola Asuh Orangtua pada Anak Usia Dini. Jurnal Obsesi : Jurnal Pendidikan Anak Usia Dini, 4(2), 766. https://doi.org/10.31004/obsesi.v4i2.300

Sudirman. (2013). Perhatian Orang Tua Dan Motivasi Belajar Siswa. Jurnal Madaniyah, 2(XI), 253.

Supriyono, Iskandar, H., \& Sucahyono. (2015). Pendidikan Keluarga Dalam Perspektif Masa Kini. Kementerian Pendidikan dan Kebudayaan Direktorat PAUD dan Dikmas.

Wahyudi, T. (2019). Paradigma Pendidikan Anak dalam Keluarga di Era Digital (Perspektif Pendidikan Islam). Ri'ayah: Jurnal Sosial Dan Keagamaan, 4(01), 31. https://doi.org/10.32332/riayah.v4i01.1489 